\title{
STUDY OF THE WATER VAPOR CONCENTRATION IN THE ATMOSPHERIC BOUNDARY LAYER 2 OVER THE BRAZIL-MALVINAS CONFLUENCE REGION
}

\author{
ESTUDO DA CONCENTRAÇÃO DE VAPOR D'ÁGUA NA CAMADA LIMITE \\ ATMOSFÉRICA SOBRE A REGIÃO DA CONFLUÊNCIA BRASIL-MALVINAS
}

\author{
Rose Ane Pereira de Freitas \\ Advisor: Dr. Ronald Buss de Souza (INPE) \\ 140 p. - Doctorate Thesis - March 27, 2017
}

\begin{abstract}
The concentration of water vapor on the marine atmospheric boundary layer (MABL) at the Brazil-Malvinas Confluence $(B M C)$ region in the Southwestern Atlantic Ocean was analyzed from 130 radiosondes collected during 10 oceanographic cruises carried out during the months of October or November from 2004 to 2015. During the same period, specific humidity and air temperature data from reanalysis (CFSR/CFSv2) and from the Atmospheric Infrared Sounder (AIRS) onboard the Aqua satellite were also used. The results of show that the thermal gradients between the warm waters of the Brazil Current (BC) and the cold waters of the Malvinas Current (MC) in BMC region are capable to produce significant differences on the MABL's water vapor content on both sides of the oceanographic front. On the average over the warmer waters of the BC the MABL is more humid. However, transients atmospheric systems, can mitigate or intensify the concentration of water vapor inside the MABL. The comparison between in situ radiosonde data and AIRS and CFSR profiles revealed that, in general, the CFSR/CFSv2 data presented a better agreement with observational data in both sides of the BMC. The AIRS data satisfactorily represent the observational data in conditions of a cloud-free atmosphere.
\end{abstract}

RESUMO. A concentração de vapor d'água na camada limite atmosférica marítima (CLAM) na região da Confluência BrasilMalvinas (CBM) no Oceano Atlântico Sudoeste foi analisada a partir de 130 radiossondas coletadas durante 10 cruzeiros oceanográficos realizados nos meses de outubro ou novembro de 2004 até 2015. Durante o mesmo período, também foram utilizados dados de umidade específica e temperatura do ar provenientes da reanálise (CFSR/CFSv2) e do Atmospheric Infrared Sounder (AIRS) a bordo do satélite Aqua. Os resultados mostram que os gradientes térmicos entre as águas quentes da Corrente do Brasil (CB) e as águas frias da Corrente de Malvinas (CM) na região do CBM são capazes de produzir diferenças significativas no conteúdo de vapor de água da CLAM em ambos os lados da frente oceanográfica. Em média, sobre as águas mais quentes do $\mathrm{CB}$, o CLAM é mais úmido. Entretanto, sistemas atmosféricos transientes podem mitigar ou intensificar a concentração de vapor de água dentro do CLAM. A comparações entre os dados mostraram que, em geral, os dados do CFSR/CFSv2 apresentaram melhor concordância com os dados observacionais em ambos os lados da CBM. Os dados do AIRS representam satisfatoriamente os dados observacionais em condições atmosféricas livre de nuvens. 